\title{
The effects of poly I:C stimulation of primary bronchial epithelial cells and TSLP secretion on CD34+ progenitor cell eosinophil and basophil differentiation
}

\author{
Ashley Yu*, Claudia CK Hui, Judah A Denburg \\ From Canadian Society of Allergy and Clinical Immunology Annual Scientific Meeting 2013 \\ Toronto, Canada. 3-6 October 2013
}

\section{Background}

In asthmatic lungs, elevated levels of thymic stromal lymphopoetin (TSLP) are linked to eosinophilic inflammation and disease severity [1]. TSLP is involved in initiating a TH2 inflammatory response, through activation of $\mathrm{T}$ cells, and recently, CD34+ hemopoietic progenitor cells $[2,3]$. However, the biological effects of epithelial-derived TSLP on human peripheral blood (PB) CD34+ progenitor eosinophil-basophil (Eo/B) lineage commitment have not been described. The aim of the current study is to examine the effects of primary bronchial epithelial cell-derived TSLP on CD34+ hemopoietic progenitor differentiation.

\section{Methods}

Primary bronchial epithelial cells (PBEC) grown in airliquid interface were apically stimulated with media or varying doses of polyinosinic:polycytidylic acid (Poly I:C; $1,10,25$, and $50 \mathrm{~g} / \mathrm{mL}$ ) and cultured in the presence or absence of PB CD34+ cells in the basolateral compartment overnight. Supernatant was collected and analyzed for cytokine/chemokine secretion using Luminex assays. Overnight co-cultured PB CD34+ cells were (1) cultured in methylcellulose colony assays to assess for the mean numbers of Eo/B colony-forming units (CFU) (colonies were defined as $\geq 40$ cells) after $14 \mathrm{~d}$; or (2) assessed for TSLPR expression using flow cytometry.

\section{Results}

Preliminary data demonstrates that overnight stimulation of PBEC with poly I:C in the absence of PB CD34+ cells

\footnotetext{
* Correspondence: yuam@mcmaster.ca

Department of Medicine and Clinical Immunology, McMaster University, Hamilton, Ontario, L8S 4L8, Canada
}

induced a dose-dependent release of IL-4, IL-5, IL-13, TNF eotaxin-1, and MCP-1; however, failed to secrete detectible levels of IL-1 $\beta$ and IFN-. Poly I:C at $10 \mu \mathrm{g} / \mathrm{mL}$ enhanced TSLP and TARC secretion while at $50 \mu \mathrm{g} / \mathrm{mL}$, poly I:C enhanced IL-33 secretion from PBEC compared to unstimulated control. Furthermore, basal levels of IL-3, IL-6, IL-8, MDC, and RANTES were detected from rested $\mathrm{PBEC}$, with no observable trend in secretion following poly I:C stimulation. Finally, PB CD34+ cells co-cultured overnight with poly I:C-stimulated PBEC have been cultured in methylcellulose colony assays and waiting for Eo/B CFU to be counted.

\section{Conclusions}

In conclusion, our co-culture system will allow for the establishment of epithelial-derived TSLP activity and its influence on CD34+ progenitor Eo/B differentiation. In the future, we would like to examine whether PBEC obtained from atopic vs. non-atopic individuals results in distinct progenitor response.

\section{cknowledgements \\ I would like to thank the AllerGen Network for the AllerGen Summer}

References

Increased expression of immunoreactive thymic stromal lymphopoietin in patients with severe asthma. J Allergy Clin Immunol 2012, 129:104-11, e1-9.) rinters.

Thymic Stromal Lymphopoietin: A Promising Therapeutic Target for Allergic Diseases. Int Arch Allergy Immunol 2013, 160:18-26. 
3. Kimura S, Pawankar R, Mori S, Nonaka M, Masuno S, Yagi T, Okubo K: Increased Expression and Role of Thymic Stromal Lymphopoietin in Nasal Polyposis. Allergy Asthma Immunol Res 2011, 3:186.

doi:10.1186/1710-1492-10-S1-A47

Cite this article as: Yu et al:: The effects of poly I:C stimulation of primary bronchial epithelial cells and TSLP secretion on CD34+ progenitor cell eosinophil and basophil differentiation. Allergy, Asthma \& Clinical Immunology 2014 10(Suppl 1):A47.

Submit your next manuscript to BioMed Central and take full advantage of:

- Convenient online submission

- Thorough peer review

- No space constraints or color figure charges

- Immediate publication on acceptance

- Inclusion in PubMed, CAS, Scopus and Google Scholar

- Research which is freely available for redistribution

Submit your manuscript at www.biomedcentral.com/submit
Ciomed Central 